\title{
ANALISIS GAYA GEMPA BANGUNAN RUMAH TINGGAL DI WILAYAH GEMPA TINGGI
}

\author{
Alfian Wiranata Zebua \\ Program Studi Pendidikan Teknik Bangunan FPTK \\ IKIP Gunungsitoli \\ E-mail : alfianzeb@yahoo.com
}

\begin{abstract}
Abstrak
Model struktur yang dianalisis yaitu gedung beraturan lantai 4 untuk rumah tinggal. Distribusi beban gempa statik diperoleh sesuai dengan SNI 1726:2012. Pengaruh beban gempa dinamik juga diperhitungkan. Hasil analisis struktur diperoleh antara lain besaran gaya geser statik 1.082,64 KN dan gaya geser dinamik, $\mathrm{Fx}=1.057 \mathrm{KN}$ dan Fy $=983,5 \mathrm{KN}$. Besaran gaya elemen kolom dan balok juga diperoleh. Reaksi tumpuan serta perpindahan titik buhul dapat diketahui dari hasil analisis yang dilakukan. Pada mode 5, partisipasi massa model yang dianalisis sudah mencapai $>90 \%$. Simpangan antar lantai yang terjadi pada model struktur tidak melebihi simpangan yang diijinkan.
\end{abstract}

Kata Kunci : Analisis Gaya Gempa, ETABS, Gedung Rumah Tinggal, Statik Ekuivalen

\begin{abstract}
Four stories building used as structure model. Static earthquake loads distribution according to SNI 1726:2012. The effect of dynamic earthquake loads also considered. The result of structural analysis determined using ETABS. It produces static shear force 1.082,64 KN and dynamic shear force, $F x=1.057 \mathrm{KN}$ and $F y=983,5 \mathrm{KN}$. Colomn and beam forces also determined. Support reactions and point displacements determined through structural analysis. Mass modal participation has been reach over $90 \%$ at mode 5. Story drift checked to allowable strory drift.
\end{abstract}

Keywords : Earthquake Loads Analysis, ETABS, Residential Building, Static Ekuivalent

\section{A. PENDAHULUAN}

Wilayah Indonesia adalah salah satu wilayah yang memiliki kondisi geologi yang menarik karena gugusan kepulauannya dibentuk oleh lempenglempeng tektonik, Indonesia merupakan daerah pertemuan 3 (tiga) lempeng tektonik besar yaitu lempeng IndoAustralia, Eurasia dan lempeng Pasifik. Tumbukan lempeng Eurasia dan lempeng India-Australia mempengaruhi Indonesia bagian barat (lepas pantai Sumatera, Jawa dan Nusa Tenggara), sedangkan pada Indonesia bagian timur (utara Papua dan Maluku Utara), dua lempeng tektonik ini ditubruk lagi oleh lempeng Samudra Pasifik dari arah timur.

Kepulauan Nias sebagai salah satu gugusan pulau di pantai barat Sumatera berada di jalur yang dikenal dengan 
sebutan 'ring of fire' sepanjang jalur pertemuan antara lempeng Eurasia dan lempeng India Australia. Kondisi geografis tersebut mengakibatkan kepulauan Nias mengalami gempa dengan kuantitas yang cukup tinggi. Peristiwa gempa 28 Maret 2005 di Kepulauan Nias adalah salah satu peristiwa yang menyatakan kerawanan letak geografis Indonesia terhadap kemungkinan terjadinya gempa bumi. Kerusakan yang masif terjadi menimbulkan korban jiwa maupun materi.

Perkembangan di bidang konstuksi pada masa sekarang sangat pesat baik dalam hal pelaksanaan konstuksi maupun dalam hal perangkat lunak komputer untuk desain struktur bangunan. Analisis struktur dapat dilakukan dengan lebih cepat dan mudah menggunakan perangkat lunak komputer. CSi (Computer and Structure, Inc.) dari Berkeley, California USA yang awalnya mengeluarkan perangkat lunak SAP80, SAP90, SAP200 tidak ketinggalan pula mengeluarkan ETABS, yang merupakan perangkat lunak untuk analisis dan desain struktur khusus untuk bangunan gedung. Dengan menggunakan program ETABS, pembuatan atau perubahan model, melakukan analisis dapat dilakukan secara langsung.

Berdasarkan fakta bahwa potensi gempa di Kota Gunungsitoli Kepulauan Nias sangat besar, maka sangat perlu diketahui besaran beban gempa yang dialami oleh struktur bangunan. Gayagaya akibat beban gempa tersebut digunakan sebagai dasar untuk desain bangunan baik rumah tinggal maupun untuk peruntukan lain. Ketersediaan perangkat lunak ETABS untuk melakukan analisis beban gempa digunakan untuk memperoleh besaran gaya pada stuktur bangunan.

\section{B. TINJAUAN PUSTAKA}

\section{Pengertian Gempa}

Gempa bumi merupakan fenomena alam yang sudah tidak asing lagi bagi kita semua, karena seringkali diberitakan adanya suatu wilayah dilanda gempa bumi, baik yang ringan maupun yang sangat dahsyat, menelan banyak korban jiwa dan harta, meruntuhkan bangunan-bangunan dan fasilitas umum lainnya. Gempa bumi disebabkan oleh adanya pelepasan energi regangan elastis batuan pada litosfir. Semakin besar energi yang dilepas semakin kuat gempa yang terjadi.

\section{Mekanisme Gempa Bumi}

Gempa bumi adalah getaran tanah yang ditimbulkan oleh lewatnya gelombang seismik yang dipancarkan oleh suatu sumber energi elastik yang dilepaskan secara tiba-tiba. Pelepasan energi elastik tersebut terjadi pada saat batuan di lokasi sumber gempa tidak mampu menahan gaya yang ditimbulkan oleh gerak relatif antar blok batuan, daya tahan batuan menentukan besaran kekuatan gempa. Teori yang dapat menjelaskan tentang energi elastik yang dapat diterima adalah pergeseran sesar dan teori kekenyalan elastis (elastic rebound theory). Teori ini menjelaskan jika permukaan bidang sesar saling bergesekan batuan akan mengalami deformasi (perubahan wujud) jika perubahan tersebut melampaui batas elastisitas atau regangannya, maka batuan akan patah (rupture) dan akan kembali ke bentuk asalnya (rebound).

Sebagai ilustrasi dapat dibayangkan sebuah per atau pegas yang ditekan kemudian dilepaskan mendadak, atau sebuah tongkat atau penggaris yang rigid yang ditekuk sampai patah ketika kembali keposisi asalnya maka terjadi getaran. Energi elastik yang dilepaskan 
merambat ke permukaan hanya sebagian kecil yang akan diubah menjadi gelombang seismik yang dipancarkan ke segala jurusan sedangkan sebagian energi akan diubah menjadi energi potensial dan energi panas.

\section{Metode Analisis Gaya Gempa}

Metode analisis gempa yang digunakan untuk merencanakan bangunan tahan gempa dapat diklasifikasikan menjadi 2 (dua), yaitu analisis statik dan analisis dinamik. Dalam menganalisis perilaku struktur yang mengalami gaya gempa, semakin teliti analisis dilakukan, perencanaannya semakin ekonomis dan dapat diandalkan.

Untuk bangunan satu tingkat dapat direncanakan hanya dengan menetapkan besarnya beban lateral yang dapat ditahan elemen struktur dan dengan mengikuti ketentuan-ketentuan dalam peraturan. Untuk bangunan berukuran sedang, prosedur analisis dapat dilakukan dengan metode analisis statik sesuai dengan prosedur yang ditentukan dalam peraturan. Untuk bangunan yang besar dan mempunyai nilai kepentingan yang besar harusmenggunakan metode analisis dinamik. Selain itu, analisis dinamik juga harus dilkakukan untuk struktur yang mempunyai kekakuan atau massa yang berbeda-beda tiap tingkatnya.

Namun, pemilihan metode analisis antara analisis statik dan dinamik umumnya ditentukan dalam peraturan perencanan yang berlaku. Pemilihan metode analisis tergantung pada bangunan tersebut apakah termasuk struktur gedung beraturan atau tidak beraturan. Jika suatu bangunan termasuk struktur bangunan beraturan yang didefinisikan dalam peraturan perencanan, maka analisis gempa dilakukan dengan analisis statik. Sebaliknya, jika suatu struktur termasuk struktur bangunan tidak beraturan, maka analisis gempa dilakukan dengan cara dinamik.

Analisis perancangan struktur bangunan terhadap pengaruh beban gempa secara statis, pada prinsipnya adalah menggantikan gaya-gaya horizontal yang bekerja pada struktur akibat pergerakan tanah dengan gayagaya statis yang ekivalen, dengan tujuan penyederhanaan dan kemudahan di dalam perhitungan. Metode ini disebut Metode Gaya Lateral Ekivalen (Equivalent Lateral Force Method). Pada metode ini diasumsikan bahwa gaya horizontal akibat gempa yang bekerja pada suatu elemen struktur, besarnya ditentukan berdasarkan hasil perkalian antara suatu konstanta berat atau massa dari elemen struktur tersebut.

\section{Gaya Gempa Statik Ekuivalen}

Gaya gempa statik ekuivalen diperoleh sesuai dengan peraturan gempa terbaru Indonesia yaitu SNI 1726:2012. Pada analisis statik ekuivalen ada dua metode pembebanan yang bisa dilakukan diantaranya dengan menggunakan data gempa yang sudah ada, User Loads dan metode User Coefficient. User Loads merupakan pembebanan gempa statis yang dilakukan pada pemodelan ETABS dimana gaya gempa yang di-assign ke dalam program merupakan hasil hitungan secara manual dan diletakkan pada pusat massa setiap lantai dengan mengasumsikan eksentrisitas 0,05.

User Coefficient merupakan pembebanan gempa statis yang dilakukan pada ETABS dimana gaya gempa tidak dihitung langsung secara manual tetapi cukup dengan mengisi nilai koefisien gempa (c) dan faktor ketinggian tingkat $(\mathrm{k})$ pada user coefficient saja dan selanjutnya gaya 
gempa dihitung secara otomatis oleh perangkat lunak.

\section{Perangkat Lunak ETABS}

ETABS (Extended 3D Analysis of Building Systems) adalah program komputer yang digunakan khusus untuk analisis dan desain bangunan gedung. Konsep ini sudah dipikirkan sejak 35 tahun yang lalu oleh para ahli dibidang Teknik Sipil. Dengan menggunakan program ETABS, pembuatan atau perubahan model, melakukan analisis, merancang atau mendesain dan mengoptimalkan desain, semuanya langsung dapat dikerjakan melalui single interface yang terintergrasi dengan Microsoft Windows.

Hasil keluaran berupa tampilan grafis yang meliputi hasil analisis gayagaya elemen atau tegangan, desain struktur baja atau beton, displacement langsung dapat diketahui. Hasil analisis dan desain dapat dipilih untuk sebagian atau keseluruhan elemen, kemudian dicetak melalui printer, atau disimpan ke dalam file. Program ETABS menyediakan empat fasilitas untuk analisis dan desain struktur, ialah membuat model, memodifikasi, menganalisis, dan mendesain struktur.

Untuk menganalisis bangunan diperlukan tahapan perhitungan beban struktur, setelah itu dilakukan analisis struktur. Perhitungan beban struktur telah disampaikan pada bagian sebelumnya. Beban-beban standar yang bekerja pada bangunan diperhitungkan. Penentuan beban gempa disesuaikan dengan SNI 1726:2012.

\section{DATA DAN ANALISA DATA \\ 1. Data}

Pada penelitian ini akan ditinjau satu model struktur gedung yaitu struktur gedung beraturan berlantai 4 . Adapun data-data teknis yang digunakan dalam analisis adalah sebagai berikut:
a. Lokasi bangunan
b. Jenis bangunan
: Rumah Tinggal
c. Konstruksi bangunan
: Struktur beton bertulang
d. Sistem struktur
: Sistem rangka pemikul momen khusus (SRPMK)
e. Dimensi struktur :
1). Plat lantai $=12 \mathrm{~cm}$
2). Plat atap $=10 \mathrm{~cm}$
3). Balok $=30 \times 50 \mathrm{~cm}$
4). Kolom lantai 1 dan 2 $=55 \times 55 \mathrm{~cm}$
5). Kolom lantai 3 dan 4 $=45 \mathrm{x} 45 \mathrm{~cm}$

f. Gambar Struktur

\section{Distribusi Gaya Gempa}

Distribusi beban gempa pada masing-masing lantai dapat dilihat pada tabel 1 .

Tabel 1. Distribusi Beban Gempa Masing-Masing Lantai

\begin{tabular}{ccccccc}
\hline & \multicolumn{5}{c}{ Kelas Situs } \\
\cline { 2 - 7 } Lantai & \multicolumn{2}{c}{ SD } & \multicolumn{2}{c}{ SC } & \multicolumn{2}{c}{ SE } \\
\cline { 2 - 7 } & $\mathbf{F i}(\mathbf{K g})$ & $\mathbf{F i}(\mathbf{K N})$ & $\mathbf{F i}(\mathbf{K g})$ & $\mathbf{F i}(\mathbf{K N})$ & $\mathbf{F i}(\mathbf{K g})$ & $\mathbf{F i}(\mathbf{K N})$ \\
\hline 4 & $72,971.70$ & 729.72 & $63,242.14$ & 632.42 & $116,754.73$ & $1,167.55$ \\
3 & $84,583.36$ & 845.83 & $73,305.58$ & 733.06 & $135,333.37$ & $1,353.33$ \\
2 & $57,742.84$ & 577.43 & $50,043.80$ & 500.44 & $92,388.55$ & 923.89 \\
1 & $26,579.30$ & 265.79 & $23,035.39$ & 230.35 & $42,526.87$ & 425.27 \\
0 & 0 & 0 & 0 & 0 & 0 & 0 \\
\hline
\end{tabular}




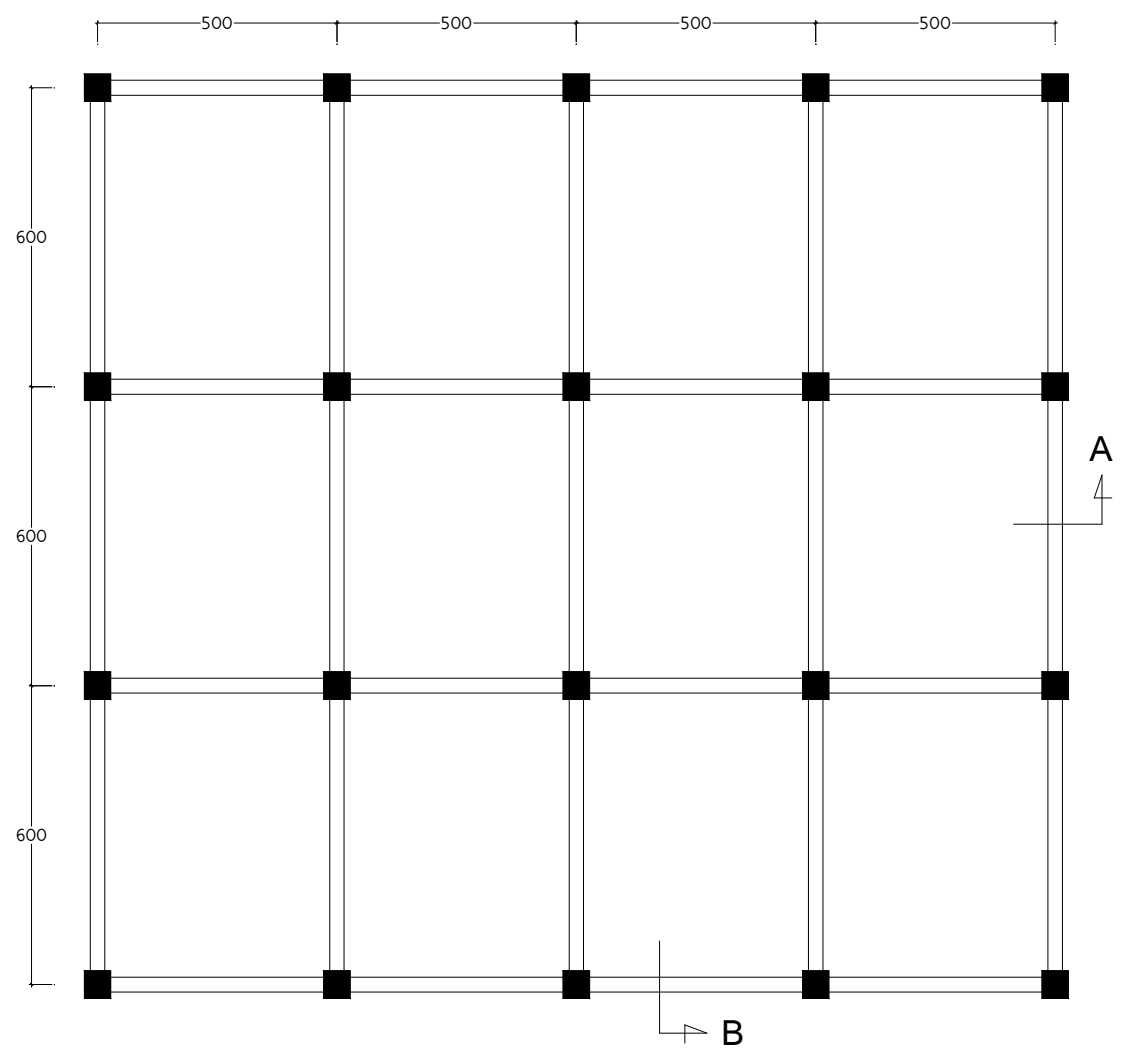

Gambar 1. Denah Model Struktur

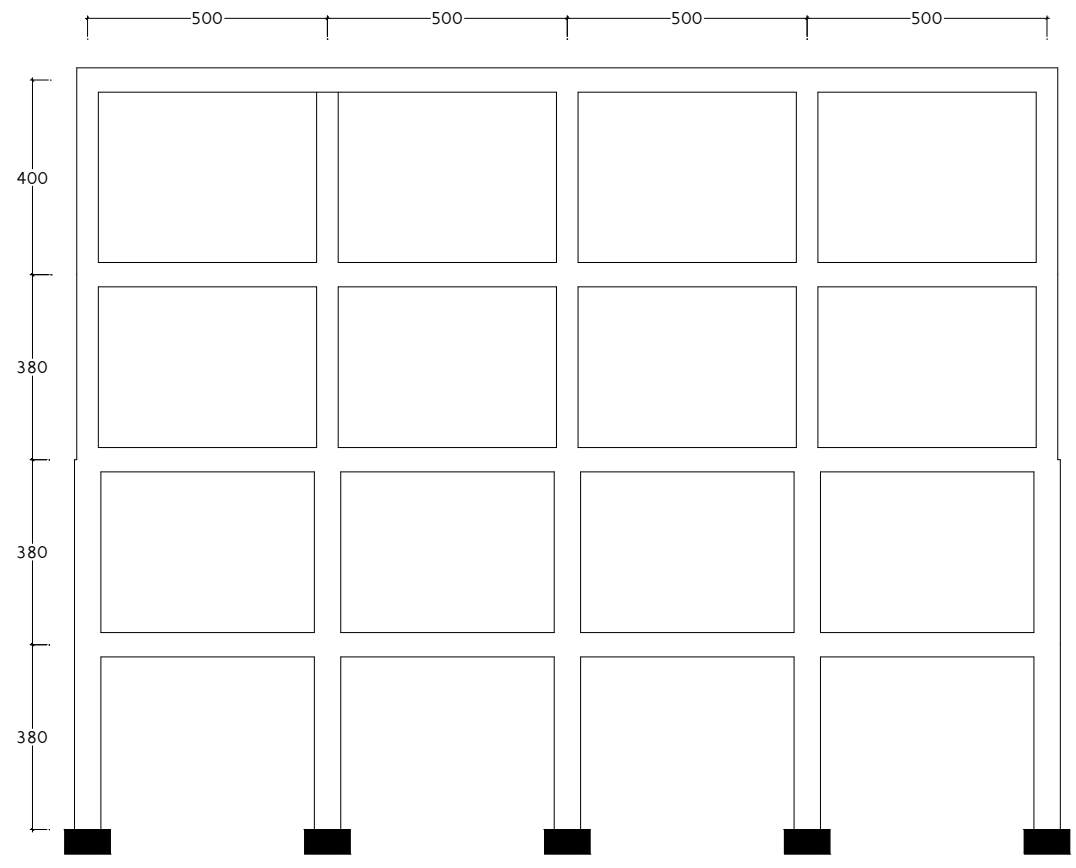

Gambar 2. Potongan A-A 


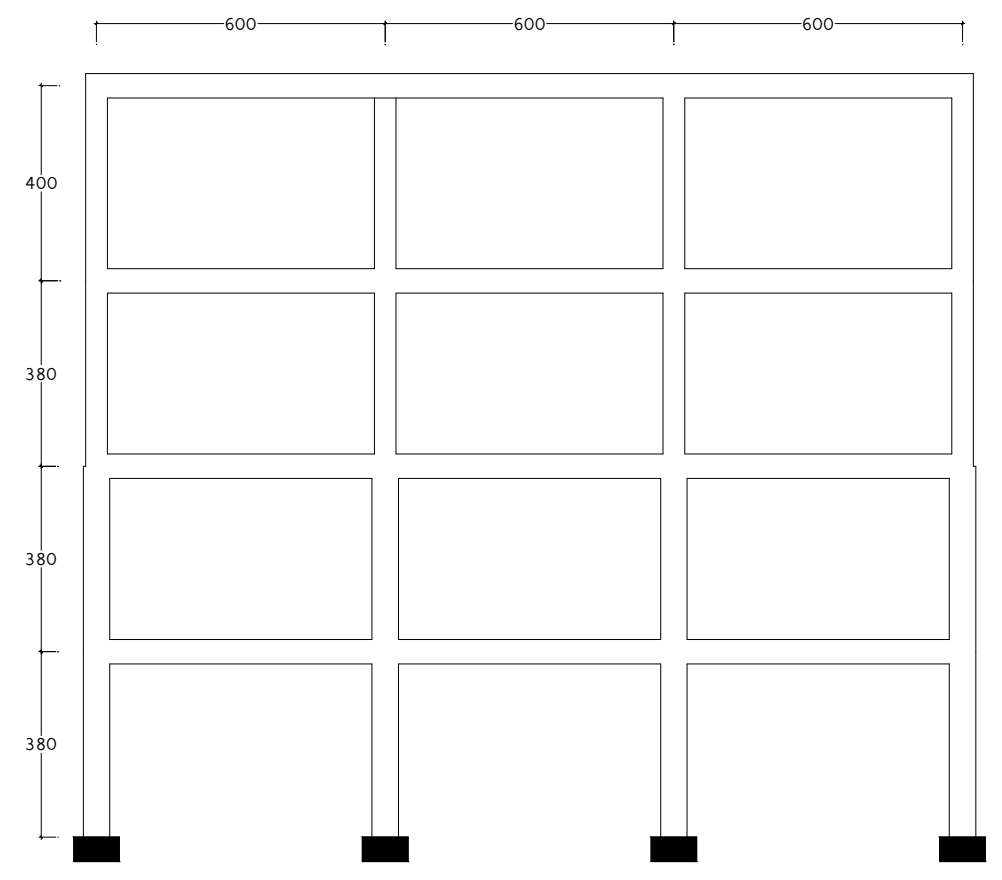

Gambar 3. Potongan B-B

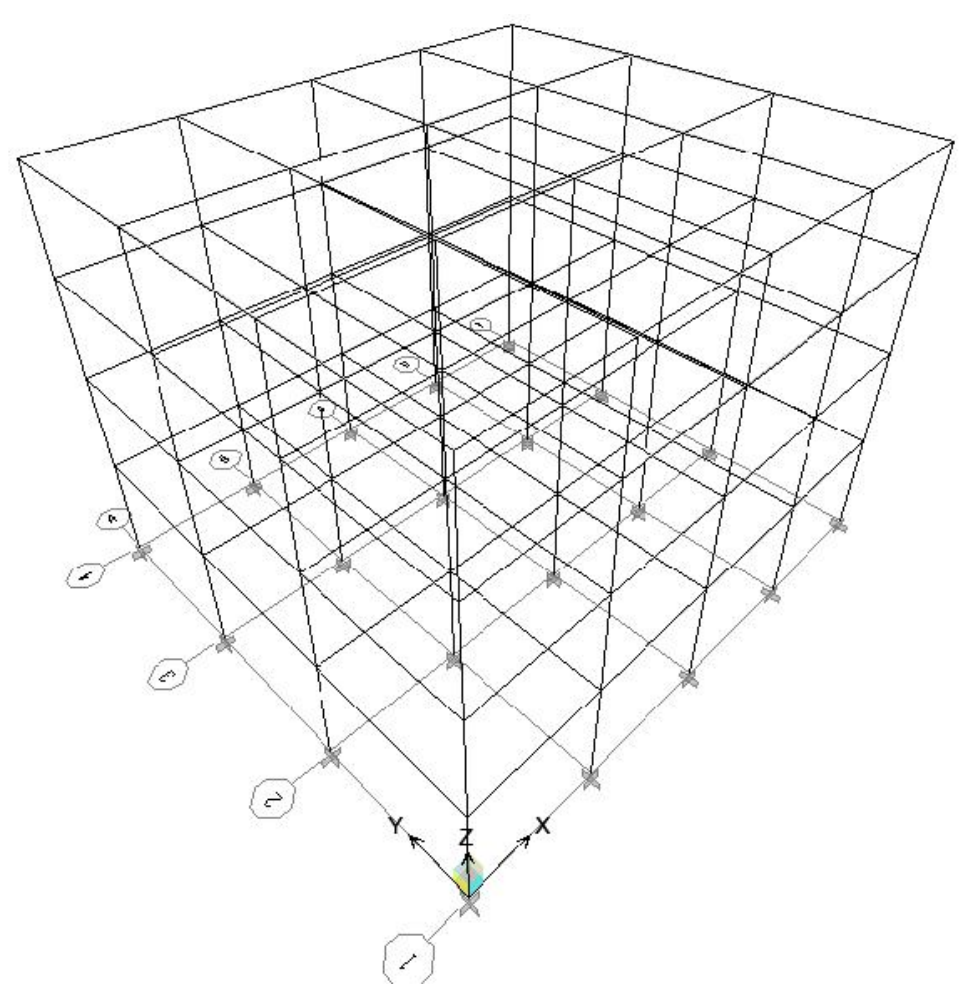

Gambar 4. Perspektif Model Stuktur 
D. HASIL DAN PEMBAHASAN

Analisis struktur dilakukan dengan menggunakan software ETABS Nonlinear Version 9.7.0. Hasil analisis struktur dapat dilihat pada Gambar 5-14.

\section{Summary Report}

Summary report dapat dilihat pada hasil analisis. Elevasi tiap lantai model stuktur dilihat pada story data. Besaran gaya geser statik yang terjadi diperoleh dari auto seismic calculation result $1.082,64 \mathrm{KN}$. Besaran gaya geser dinamik diperoleh dari total reactive forces (recovered loads) at origin, $\mathrm{Fx}=$ $1.057 \mathrm{KN}$ dan Fy $=983,5 \mathrm{KN}$. Besaran perpindahan yang terjadi pada tiap lantai dapat dilihat pada story drift.

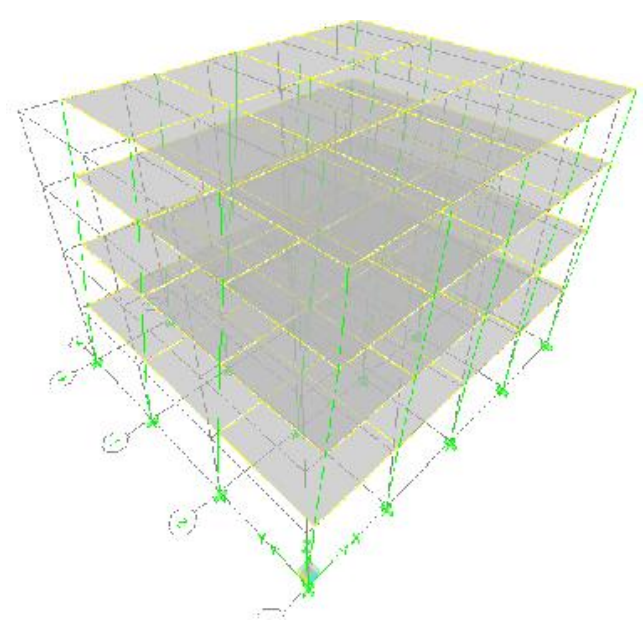

Gambar 5. Perpindahan Akibat Pengaruh Beban Gempa Statik Arah-X

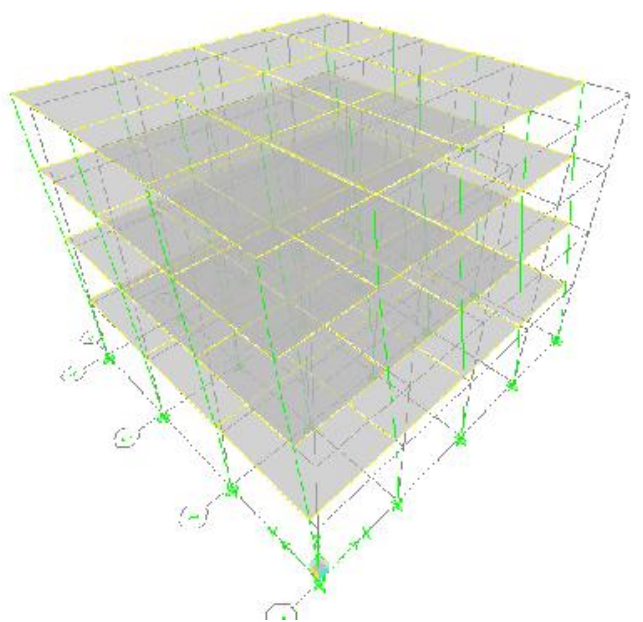

Gambar 6. Perpindahan Akibat Pengaruh Beban Gempa Statik Arah-Y 


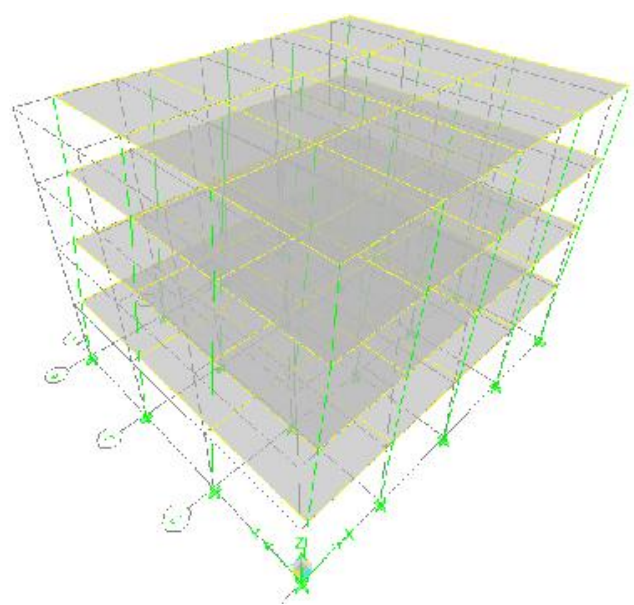

Gambar 7. Perpindahan Akibat Pengaruh Beban Gempa Dinamik Arah-X

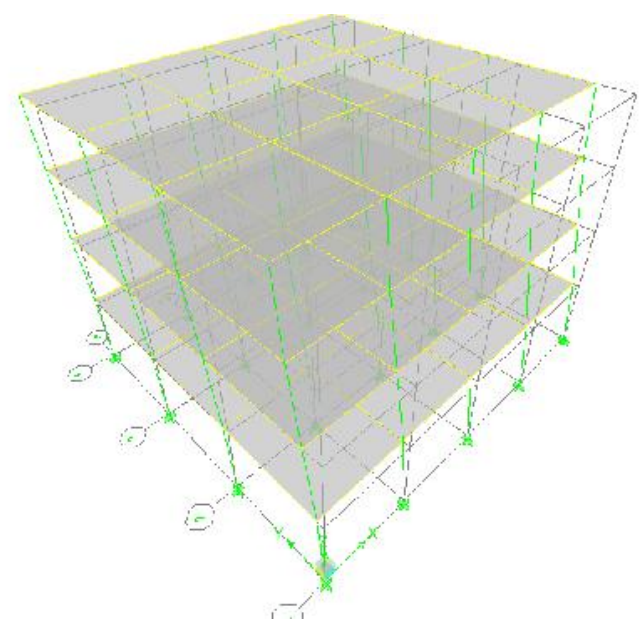

Gambar 8. Perpindahan Akibat Pengaruh Beban Gempa Dinamik Arah-Y

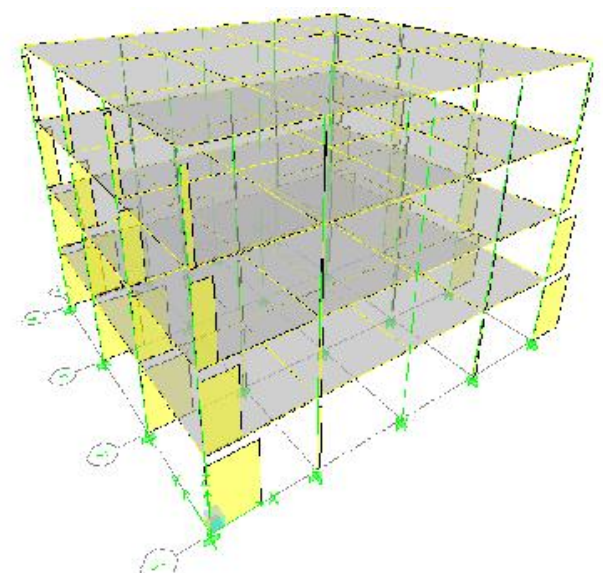

Gambar 9. Diagram Beban Normal Akibat Beban Gempa Dinamik Arah-X 


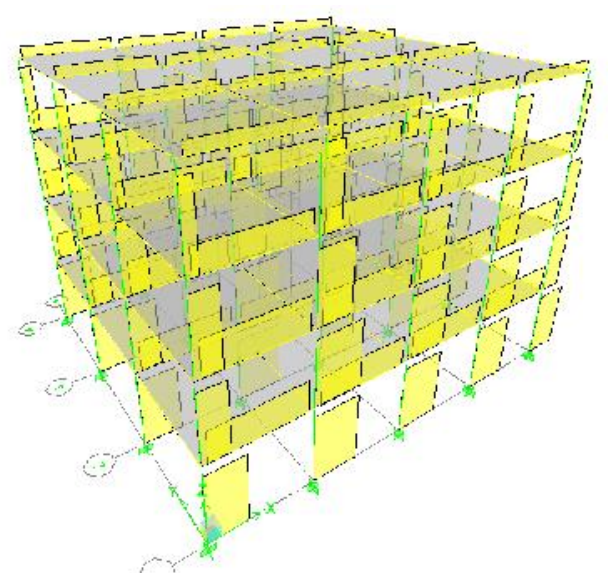

Gambar 10. Diagram Gaya Geser Akibat Beban Gempa Dinamik Arah-X

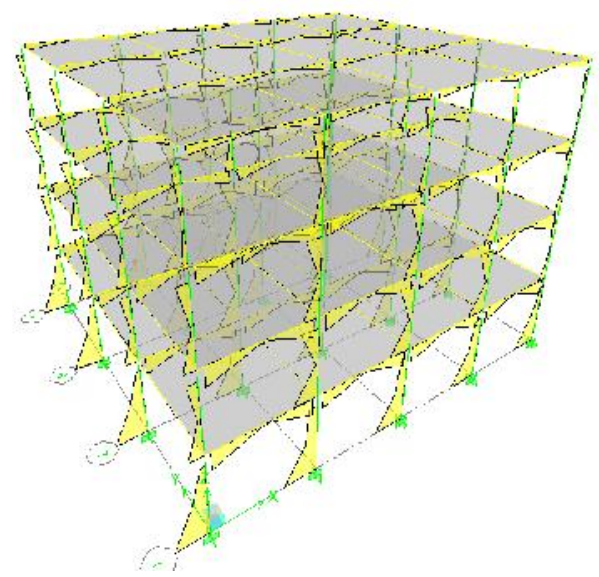

Gambar 11. Diagram Momen Akibat Beban Gempa Dinamik Arah-X

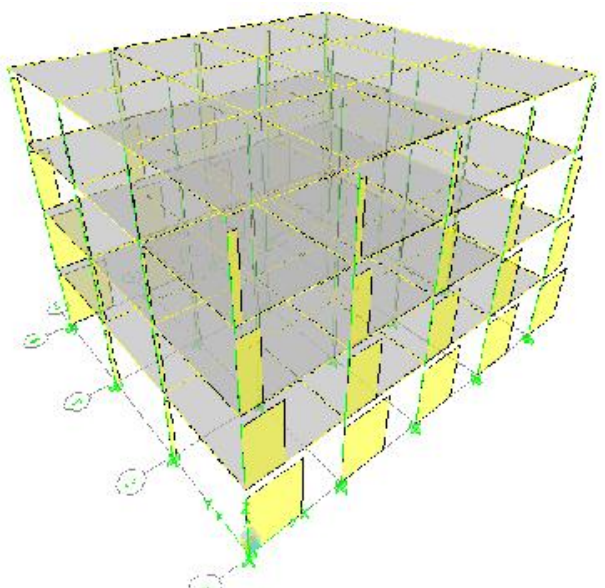

Gambar 12. Diagram Beban Normal Akibat Beban Gempa Dinamik Arah-Y 


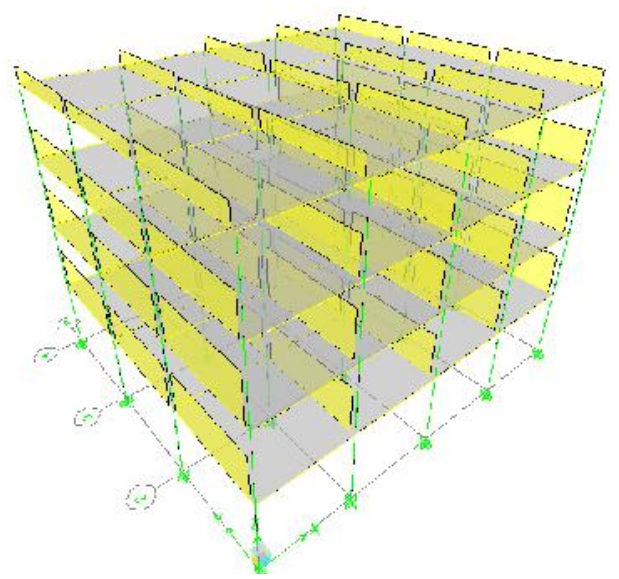

Gambar 13. Diagram Gaya Geser Akibat Beban Gempa Dinamik Arah-Y

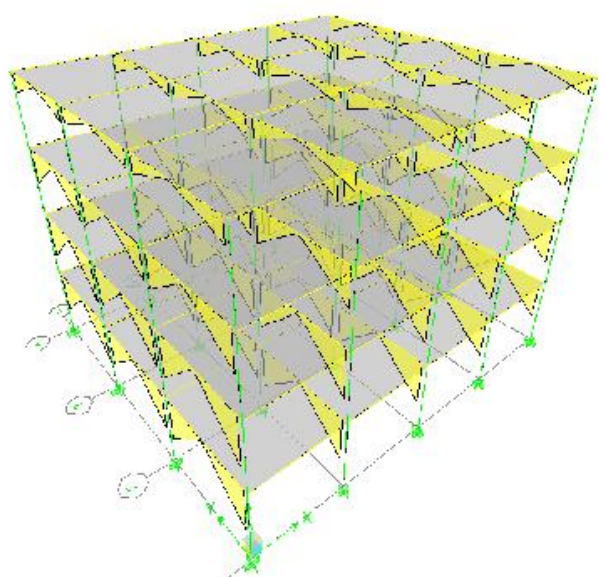

Gambar 14. Diagram Momen Akibat Beban Gempa Dinamik Arah-Y

\section{Element Forces}

Besaran gaya-gaya yang terjadi pada elemen-elemen (balok dan kolom) dapat dilihat pada lampiran element forces. Kombinasi pembebanan disampaikan sesuai dengan masukan yang diberikan. Besaran gaya yang terjadi pada elemen kolom pada masingmasing lantai dapat dilihat pada column force envelope. Sebagai contoh pada STORY4 C1, maksudnya adalah kolom 1 pada lantai keempat. Besaran gaya yang ditampilkan adalah:

a. Gaya aksial (P), KN

b. Gaya geser (V2), KN

c. Momen (M3), KNm
MinValue, maksudnya adalah besaran gaya terkecil yang terjadi pada elemen kolom lantai dimaksud, Max Value adalah besaran gaya terbesar yang terjadi pada elemen kolom lantai dimaksud. Min Case adalah beban atau kombinasi pembebanan yang mengakibatkan besaran gaya terkecil yang dialami elemen, sedangkan Max Case adalah beban atau kombinasi pembebanan yang mengakibatkan besaran gaya terbesar yang dialami elemen. Besaran nilai Min Value dan Max Value disesuaikan dengan arah gaya yang terjadi sesuai dengan perjanjian tanda pada ketiga jenis gaya. 
Besaran gaya aksial (P), gaya geser (V2) dan momen (M3) yang diperoleh akan digunakan sebagai dasar perencanaan dimensi struktur yang dibutuhkan. Pada masing-masing lantai dipilih nilai terbesar gaya yang terjadi pada elemen kolom.

Besaran gaya yang terjadi pada elemen balok pada masing-masing lantai dapat dilihat pada beam force envelope. Pada model stuktur yang dianalisis, gaya-gaya maksimum yang terjadi pada masing-masing lantai disampaikan pada Tabel 2 dan 3 .

\section{Perpindahan Titik Buhul}

Besaran nilai perpindahan titik buhul disampaikan pada point displacement envelopes. Nilai perpindahan disampaikan pada tiga arah sumbu $\mathrm{X}, \mathrm{Y}$ dan $\mathrm{Z}$ serta berotasi pada masing-masing sumbu tersebut. Besaran nilai perpindahan titik buhul pada masing-masing lantai disampaikan pada tabel 4.

Tabel 2. Besaran Gaya Elemen Kolom

\begin{tabular}{cccc}
\hline Lantai ke- & P $(\mathbf{K N})$ & V2 $(\mathbf{K N})$ & M3 $(\mathbf{K N}-\mathbf{m})$ \\
\hline 4 & 341,75 & 41,83 & 75,681 \\
3 & 773,23 & 57,52 & 99,422 \\
2 & 1216,55 & 79,47 & 151,403 \\
1 & 1663,12 & 76,92 & 215,584 \\
\hline
\end{tabular}

Tabel 3. Besaran Gaya Elemen Balok

\begin{tabular}{cccc}
\hline Lantai ke- & P (KN) & V2 (KN) & M3 (KN-m) \\
\hline 4 & 8,30 & 106,38 & 127,452 \\
3 & 4,35 & 147,60 & 197,630 \\
2 & 3,67 & 159,04 & 226,164 \\
1 & 7,77 & 157,31 & 221,848 \\
\hline
\end{tabular}

Tabel 4. Besaran Perpindahan Titik Buhul Tiap Lantai

\begin{tabular}{ccccc}
\hline Lantai Ke- & $\mathbf{U x}(\mathbf{m})$ & $\mathbf{U y}(\mathbf{m})$ & $\mathbf{U z}(\mathbf{m})$ \\
\hline 4 & 0,0249 & 0,0287 & 0,0002 \\
3 & 0,0204 & 0,0234 & 0,0001 \\
2 & 0,0126 & 0,0144 & 0,0001 \\
1 & 0,0052 & 0,0057 & 0,0001 \\
0 & 0 & 0 & 0 \\
\hline
\end{tabular}

\section{Building Method}

Building modal info memberikan informasi mengenai modal bangunan pada analisis dinamik dengan menggunakan respon spektrum. Dari modal participating mass ratios dapat dilihat bahwa pada mode 5 partisipasi massa telah mencapai lebih besar dari $90 \%$.

\section{Simpangan Antar Lantai}

Simpangan antar lantai menunjukkan kekakuan model struktur. Dari hasil analisis struktur diperoleh simpangan yang terjadi dan diperiksa apakah simpangan yang terjadi memenuhi standar peraturan gempa Indonesia. 
Tabel 5. Simpangan Antar Lantai

\begin{tabular}{|c|c|c|c|c|c|}
\hline Lantai & hx (mm) & бxe (mm) & Cd $\delta x e / I(m m)$ & $(\mathbf{m m})$ & a ijin (mm) \\
\hline 4 & 3800 & 24.9 & 136.95 & 24.75 & 76 \\
\hline 3 & 3800 & 20.4 & 112.2 & 42.9 & 76 \\
\hline 2 & 3800 & 12.6 & 69.3 & 40.7 & 76 \\
\hline 1 & 4000 & 5.2 & 28.6 & 28.6 & 80 \\
\hline
\end{tabular}

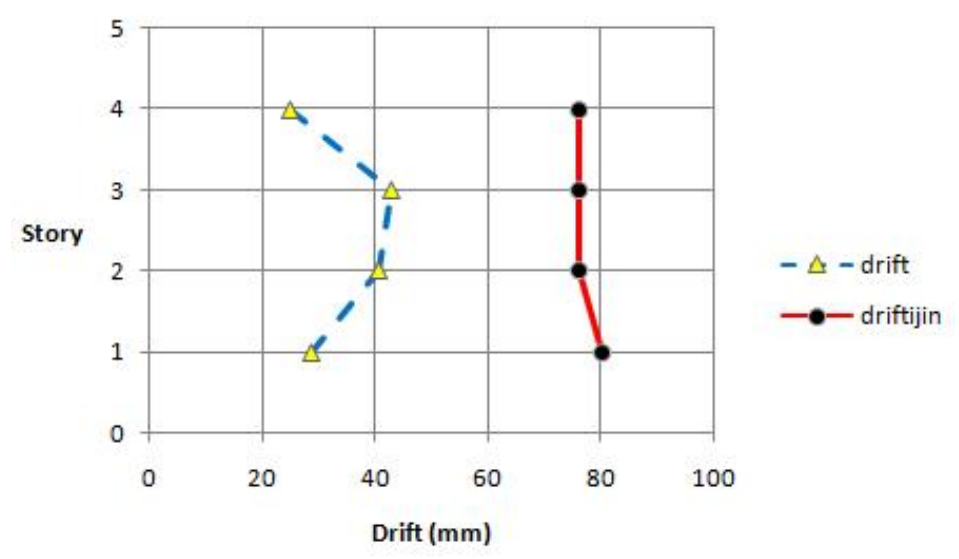

Gambar 15. Simpangan Antar Lantai Terjadi dengan Simpangan Ijin

\section{E. KESIMPULAN}

Analisis model struktur dengan menggunakan software ETABS Nonlinear Version 9.7.0., dapat memberikan data yang diperlukan berupa gaya aksial, geser dan momen untuk perencanaan struktur bangunan lebih lanjut. Simpangan antar lantai yang terjadi pada model struktur yang dianalisis memenuhi standar yang ditetapkan oleh pemerintah sesuai dengan SNI 1726:2012.

\section{DAFTAR PUSTAKA}

Arfiadi Y., 2011, Analisis Struktur dengan Metode Matriks Kekakuan, Cahaya Atma Pustaka.

BSN, 2012, Tata cara perencanaan ketahanan gempa untuk struktur bangunan gedung dan non gedung SNI 1726:2012, BSN, Jakarta.
BSN, 2013, Beban minimum untuk perancangan bangunan gedung dan struktur lain SNI 1726:2013, BSN, Jakarta.

Departemen Pekerjaan Umum, 1983, Peraturan Pembebanan Indonesia Untuk Gedung, Bandung.

Dewobroto W., 2007, Aplikasi Rekayasa Konstruksi dengan SAP 2000 Edisi Baru, Gramedia, Jakarta.

Hartuti ER., 2009, Buku Pintar Gempa Mengenal Seluk Beluk Gempa, Jenis-jenisnya, Penyebabpenyebabnya, Dampakdampaknya, DIVA Press, Yogkarta.

Kusuma G., dan Andriono T., 1993, Desain Struktur Rangka Beton Bertulang di Daerah Rawan Gempa, Erlangga, Jakarta.

Lumantarna B., 2000, Pengantar Analisis Dinamis dan Gempa, Andi Offset, Yogyakarta. 
Pawirodikromo W., 2012, Seismologi

Teknik \& Rekayasa Kegempaan,

PUSTAKA PELAJAR,

Yogyakarta.

Purwono R., 2005, Perencanaan

Struktur Beton Bertulang Tahan

Gempa sesuai dengan SNI-1726

dan SNI-2847 Terbaru, ITS

Press, Surabaya.

Suharyanto, 2013, Rekayasa Gempa (Dilengkapi Dengan Analisis Beban Gempa Sesuai SNI - 03 1726 - 2002), Kepel Press, Yogyakarta.

Tjokrodimuljo K., Teknik Gempa, Nafia Offset, Yogyakarta.
Wigroho HY., 2006, Analisis dan Desain Struktur menggunakan ETABS versi 8.4.5, FT-UAJY, Yogyakarta.

Winter G., dan Nilson AH., 1993, Perencanaan Struktur Beton Bertulang, PT Pradnya Paramita.

Zebua AW., 2016, Penentuan Besaran Beban Gempa Bangunan Rumah Tinggal di Kota Gunungsitoli Kepulauan Nias (statik ekivalen) sesuai dengan SNI 1726:2012, Jurnal DIDAKTIK, Volume 10, Nomor 1, April 2016, ISSN : 1978-144x : 1701-1714. 